\title{
Leafy és nem-leafy silókukorica hibridek összehasonlítása agronómiai tulajdonságaik, a szemtermés minósége és a biogáz kihozatal alapján
}

\author{
HEGYI ZSUZSANNA-TÓTHNÉ ZSUBORI ZSUZSANNA-RÁCZ FERENC \\ Magyar Tudományos Akadémia Mezôgazdasági Kutatóintézet, Martonvásár
}

\begin{abstract}
Összefoglalás
Tizenkét silókukorica hibridet vizsgáltunk szántóföldi kísérletben Martonvásáron, 2007-2008. évek folyamán. A kísérletben leafy (leveles) és nem-leafy silókukorica hibridek agronómiai tulajdonságait, a szemtermés minôségi paramétereit, valamint a biogáz kihozatalt hasonlítottuk össze. A vizsgált évek idôjárása különbözött egymástól, az évjárat hatása jelentôsen befolyásolta a kapott eredményeket. A 2008-ban lehullott nagy mennyiségú csapadéknak köszönhetően a hibridek elérték a genetikailag determinált magasságukat (átlagosan $274 \mathrm{~cm}$ ), miközben a 2007-es aszályos esztendóben az átlagos magasságuk csupán $238 \mathrm{~cm}$ volt. Mindkét évben a leafy hibridek nagyobbra nôttek, mint a nem-leafy, hagyományos nemesítésú silókukorica hibridek. A fốcsố fölötti legnagyobb asszimilációs levélterületet mindkét évben a kísérletben szerepló öt leafy hibrid érte el. Két év átlagában ez az érték a leafy hibrideknél 0,53-0,84 $\mathrm{m}^{2}$, a nem-leafy hibrideknél 0,35-0,45 $\mathrm{m}^{2}$ közötti intervallumban változott. A leafy hibridek nagyobb levélterületét a fốcsố fölötti nagyobb levélszám és a szélesebb levelek eredményezték. Az ideális silókukorica hibridek a nagy zöldtömeg mellett (szár, levél) kielégítô mennyiségú szemtermést is produkálnak. A kísérletben szereplő néhány leafy és nem-leafy hibrid ebből a szempontból is kiemelkedő eredményt produkált. A legnagyobb egyedi csőtömeg produkciót egy leafy hibrid (Mv Massil) érte el mindkét évben (198; 320 g), ennél a hibridnél mértük a legnagyobb fốcső fölötti levélterületet a vizsgált években. A legnagyobb keményítő tartalmakat leafy hibridek mintáiban mértük, miközben a legnagyobb fehérje- és olajtartalom a nem-leafy hibrideket jellemezte, elsôsorban a korai érésúeket. Mind a hagyományos, mind a leafy silókukorica hibridekból elvégeztettük
\end{abstract}


a biogáz kihozatali vizsgálatot. Az eredmények azt mutatták, hogy 1 kg szárazanyagra vetítve az Mv Limasil (4941/kg) és az Mv Dunasil ( 490 1/kg) leafy hibridekből képzôdött a legtöbb gáz.

Kulcsszavak: silókukorica hibridek, leafy, nem-leafy, agronómiai tulajdonságok, minőség, biogáz

\title{
Comparative analysis of leafy and non-leafy silage maize hybrids based on agronomic traits, chemical quality and biogas production
}

\author{
ZS. HEGYI-ZS. TÓTHNÉ ZSUBORI- F. RÁCZ
}

Agricultural Research Institute of the Hungarian Academy of Sciences, Martonvásár

\section{Summary}

Twelve silage maize hybrids were included in field (Martonvásár) experiments in 2007 and 2008 to compare the agronomic traits and chemical quality traits of leafy and non-leafy hybrids. The climatic data for the two experimental years differed considerably. The results reflect the differences in weather conditions. Owing to the plentiful rainfall in 2008 , the hybrids reached their genetically determined height $(274 \mathrm{~cm}$ on average), while in 2007 , the average height was only $238 \mathrm{~cm}$. In both years, a leafy hybrid was the tallest, while the shortest plants were non-leafy. The assimilation leaf area above the main ear was greatest for the five leafy hybrids in both years, with values of $0.35-0.45 \mathrm{~m}^{2}$ for conventional hybrids and $0.53-0.84 \mathrm{~m}^{2}$ for leafy hybrids, averaged over the two years. The larger leaf area in leafy hybrids could be attributed both to the larger number of leaves and to the fact that they were broader. In addition to large green mass (leaf, stalk), an ideal silage maize hybrid should also have satisfactory grain yield. Several of the leafy and non-leafy hybrids in the experiment produced favourable results. The greatest ear mass per plant was produced by Mv Massil (198; $320 \mathrm{~g}$ ), a leafy hybrid which also had the greatest leaf area above the main ear. In the present experiment, the highest starch content was obtained for a leafy hybrid, while the highest protein and oil contents were characteristic of early maturing, non-leafy hybrids. Nevertheless, three of the leafy hybrids had aboveaverage protein content. An analysis of the biogas yield from conventional and leafy silage 
hybrids showed that the leafy hybrids Mv Limasil (4941 kg-1) and Mv Dunasil ( $\left.4901 \mathrm{~kg}^{-1}\right)$ produced significantly more gas per kg dry matter.

Key words: silage maize hybrids, leafy, non-leafy, agronomic traits, grain quality, biogas

\section{Bevezetés és irodalmi áttekintés}

A Leafy hibridek legfőbb jellemzője, hogy több levéllel rendelkeznek, mint a normál hibridek. A Lfy1 gén átalakítja a növény architektúráját azáltal, hogy megnöveli a fotoszintézis szempontjából fontos csôfeletti levelek számát. Az ilyen típusú hibrideknél alacsonyabban helyezkedik el a fốcsô, megrövidülnek az internódiumok, a szár lignintartalma és a terméspotenciáljuk is nagyobb lesz. Mindezt egy domináns gén, az $L f y 1$ jelenléte okozza. Errốl a génrốl először Shaver (1983) írt részletesebben, ismertetve a gén eredetét, öröklődését, és a kukorica morfológiájára, illetve termésére gyakorolt, legtöbbször pozitív hatásait.

A nagyobb csố feletti levélszám nagyobb asszimiláló levélfelületet jelent, a növény nagyobb hatékonysággal tudja megkötni a fotoszintézishez szükséges fényenergiát, így több asszimiláta termelôdik a levelekben (Dwyer et al. 1995). A szemtelítódés és a termés szempontjából a csố feletti leveleknek van nagyobb jelentôségük, mivel ezek a levelek fiatalabbak és aktívabban fotoszintetizálnak, könnyebben szállítják a szembe a tápanyagokat, mint a csó alatti, elöregedett levelek (Subedi és Ma 2005). A megnövekedett csố feletti levélfelület miatt a leafy genotípusok vegetatív periódusa rövidebb, a szemtelítôdés idôtartama pedig hosszabb (Begna et al. 2001, Modarres et al. 1997). Mindez a termésre és a szemek minőségére pozitív hatással van, ahogy arról több szerzó is beszámolt (Stewart és Dwyer 1993, Begna et al. 2001, Modarres et al. 1997, Dijak et al. 1999).

A silókukorica minősége szempontjából a hektáronkénti minél nagyobb zöldilletve szárazanyag termés mellett kiemelkedô fontosságú a szilázs beltartalma és emészthetôsége. A keményítố tartalom, a fehérje mennyisége és minôsége (aminosav összetétele), az emészthetố zsírtartalom, a rost- és a lignintartalom, a szem/szár, szem/levél aránya, a zöld száron érés, és a lágyabb maghéjszerkezet mind a szilázs minőségét és emészthetôségét befolyásoló tényezôk. A levelek teljes növényi szárazanyagon belüli nagyobb részaránya és a cső feletti levelek nagyobb szénhidrát tartalma (Andrews et al. 2000) szintén kedvezóen befolyásolja a szilázs minőségét és emészthetôségét. Régebben az emészthetôség szempont- 
jából csak a szem magas részarányát tartották kedvezőnek, mivel a szemben halmozódnak fel az értékes tápanyagok. A silókukorica hibridek minósítésekor a hazai gyakorlatban is csak ezt a tulajdonságot vizsgálták. A leafy hibridek esetében azonban a cső feletti (nagyobb számú) levelekben is magas az asszimiláták aránya, és ezek ugyanolyan jól emészthetố formában vannak jelen, mint a szemben (Perry és Caldwell 1969).

A mezőgazdasághoz kapcsolódó biogáz termelés, silókukorica biomasszából biogáz elóállítása már bevett gyakorlat számos európai országban. Németországban 1995. óta 274-ról 3200-ra nốtt a biogáz üzemek száma (Weiland 2006, 2007, Schittenhelm 2008), a silókukorica vetésterülete pedig 2015-re elérheti az 1,7 millió ha-t (Gömann et al. 2007), ami a jelenlegi vetésterület tízszerese.

\section{Anyag és módszer}

Négy ismétléses, véletlen blokk elrendezésú kísérletet állítottunk be 20072008. években Martonvásáron, csernozjom talajon. A kétsoros parcellák mérete $8 \mathrm{~m}^{2}$ volt, soronként 31 magot vetettünk, ami 80 ezer tő/ha állománysúrúségnek felel meg. A vizsgálatba leafy és nem-leafy silókukorica hibrideket vontunk be (1. táblázat).

1. táblázat. A kísérletben vizsgált leafy és nem-leafy silókukorica hibridek

\begin{tabular}{lclc}
\hline \begin{tabular}{c} 
Leafy silókukorica \\
hibridek \\
\multicolumn{1}{c}{$(1)$}
\end{tabular} & $\begin{array}{c}\text { FAO } \\
\text { szám }\end{array}$ & \multicolumn{1}{c}{$\begin{array}{c}\text { Nem-leafy } \\
\text { silókukorica hibridek }\end{array}$} & $\begin{array}{c}\text { FAO } \\
\text { szám } \\
(2)\end{array}$ \\
\hline Limasil & 380 & Mv 241 & 260 \\
Dunasil & 390 & Mv 298 & 300 \\
Kámasil & 510 & Mv 352 & 330 \\
Mv Siloking & 580 & Maros & 330 \\
Mv Massil & 610 & Mv NK 333 & 390 \\
& & Mv TC 434 & 480 \\
& & Maxima & 580 \\
\hline
\end{tabular}

Table 1. Leafy and non-leafy silage maize hybrids tested in the experiment. (1) Leafy silage maize hybrids, (2) FAO number, (3) Non-leafy silage maize hybrids.

Szántóföldön mértük a nem-leafy (hagyományos nemesítésú) és a leafy silókukorica hibridek agronómiai tulajdonságait (növény- és fốcsőmagasság, fốcső fölötti levélszám, fốcsőnél lévô levél hossza és szélessége, egyedi csôtö- 
meg produkció). A főcső fölötti levélterületet a Montgomery (1906) képlettel számoltuk ki. A fontosabb terméselemeket laboratóriumban mértük (fôcsô hossza, ezerszemtömege). A szemtermés minőségi paramétereit (fehérje-, olaj-, keményítôtartalom) NIR készülékkel határoztuk meg. Augusztus folyamán 4 leafy (Limasil, Dunasil, Mv Siloking, Mv Massil) és 4 nem-leafy (Maros, Mv NK 333, Mv TC 434, Maxima) fajtákból mintát vettünk (föld feletti részeiket szecskáztuk), majd ezeket a mintákat átadtuk biogáz kihozatali vizsgálatok elvégzésére. A vizsgálatokat Sopronhorpácson, a BETA Kutató Intézetben végezték el. A biogáz képződés alapvetően két szakaszból áll, egy fermentációs és egy metánképződési szakaszból. A fermentációs szakasz fázisaiban (hidrolízis, savas fázis) a nagy molekulájú szerves anyagok lebontása, feltárása történik, enzimek és fermentációs baktériumok közremúködésével. A maximális lebomlásra törekedve a különböző hibridek gázkihozatalát és a termelt biogáz mennyiségét alacsony szárazanyag tartalom mellett, mezofil körülmények között vizsgálták.

A vizsgált évek időjárása nagymértékben különbözött egymástól. A martonvásári termőhelyen, 2007-ben a lehullott csapadék mennyisége $265 \mathrm{~mm}$ volt, $47 \mathrm{~mm}$-rel kevesebb, mint a sokéves átlag (1. ábra). Ugyanakkor a 2008-as év ideális volt csapadék szempontjából, a kísérleti térre 482,7 mm eső esett, 170,7 mm-rel több, mint a 30 éves átlag. A virágzás előtti időszakban (május-június) 2007-ben 73,4 mm, 2008-ban 236,6 mm csapadék hullott. A kukorica virágzása idején 2008-ban (júliusban) 76,8 mm esô esett, 2007-ben csupán $25 \mathrm{~mm}$. A két év átlaghőmérséklete alig különbözött egymástól, 2007-ben $18,2^{\circ} \mathrm{C}$ fok, 2008-ban $18,0^{\circ} \mathrm{C}$ volt az átlaghőmérséklet, a 30 éves átlag $17,7^{\circ} \mathrm{C}$. Miközben 2007-ben a sokéves átlagtól elmaradt a lehullott csapadék mennyisége, eközben a hőségnapok száma emelkedett, a vegetációs periódusban 58 nap volt (39 nap a sokéves átlag). A kritikus időszakban, virágzáskor 20 napon keresztül 30 fok felett volt az átlaghőmérséklet, a tartós légaszályt megsínylették a növények. A hôségnapok száma 2008-ban mérséklődött (42 nap), júliusban (virágzáskor) csupán 14 napon keresztül volt 30 fok felett az átlaghőmérséklet.

A statisztikai elemzésekhez az AGROBASE'99 szoftver kéttényezós variancia-analízisét használtuk. 
1. ábra. A lehullott csapadék mennyisége (10 naponként) a vegetációs periódusban, a vizsgált években ( $\mathrm{mm}$ )

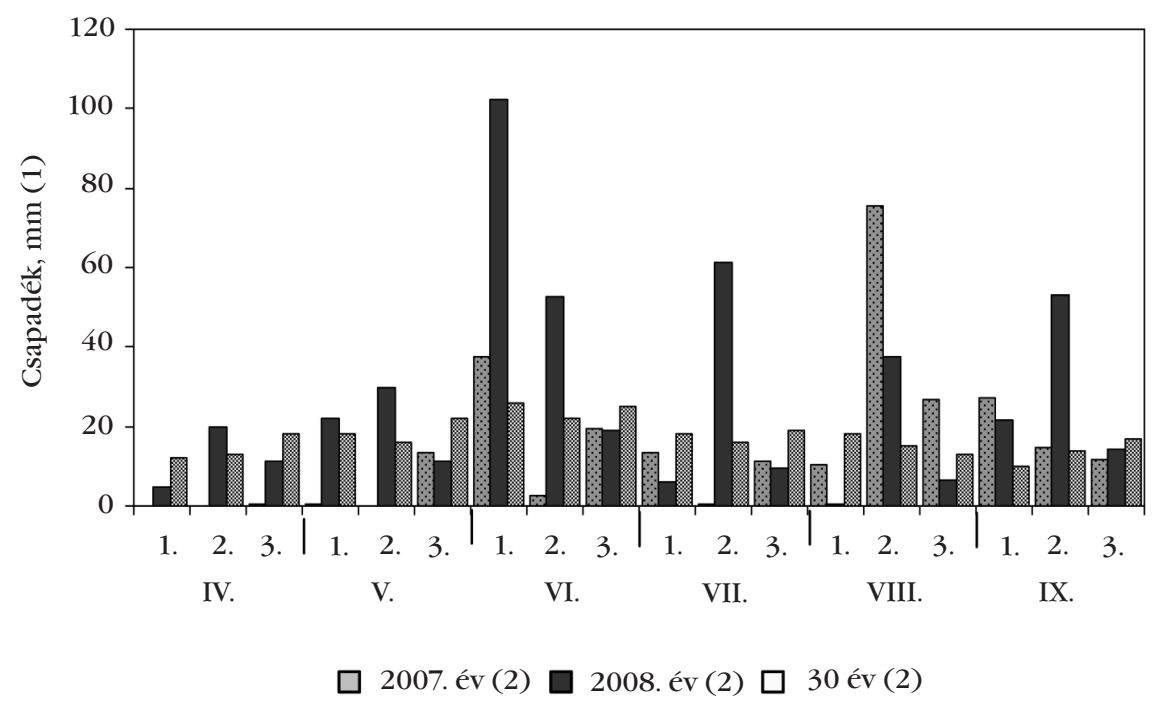

Figure 1. Rainfall quantities for each ten days of the vegetation period in the experimental years (mm). (1) Rainfall, (2) Year.

\section{Kísérleti eredmények}

\section{Növény-és fö́csômagasság}

A kísérletben szereplô hibridek átlagos magassága 2007-ben 238, 2008-ban $274 \mathrm{~cm}$ volt (2. ábra). A 2008-ban lehullott bôséges csapadék mennyisége eredményezte, hogy a növények elérték a genetikailag determinált magasságukat. Az aszályos 2007-es évben a nem-leafy hibridek $234 \mathrm{~cm}$ átlagos nagyságot értek el, a leafy hibridek $243 \mathrm{~cm}$-t (a különbség statisztikailag igazolható volt). 2008-ban, a hibridek növekedési idôszakában (május, június) lehullott csapadék mennyiségének köszönhetôen mind a leafy hibridek $(283 \mathrm{~cm})$, mind a nem-leafy hibridek ideális nagyságúra nôttek $(267 \mathrm{~cm})$. Növény- és fốcsőmagasság szorosan korreláló tulajdonságok, 2007-ben $103 \mathrm{~cm}$ volt a fốcsövek átlagos magassága, 2008-ban $112 \mathrm{~cm}$. Az irodalmi adatokkal összhangban a leafy hibridek fốcsövei mindkét évben alacsonyabban helyezkedtek el (102; 111 $\mathrm{cm})$, mint a nem-leafy hibridek fốcsövei $(104 ; 113 \mathrm{~cm})$. A különbségek statisztikailag igazolhatóak voltak. 
2. ábra. A kísérletben szereplö leafy és nem-leafy silókukorica hibridek növénymagassága a vizsgált években (cm)

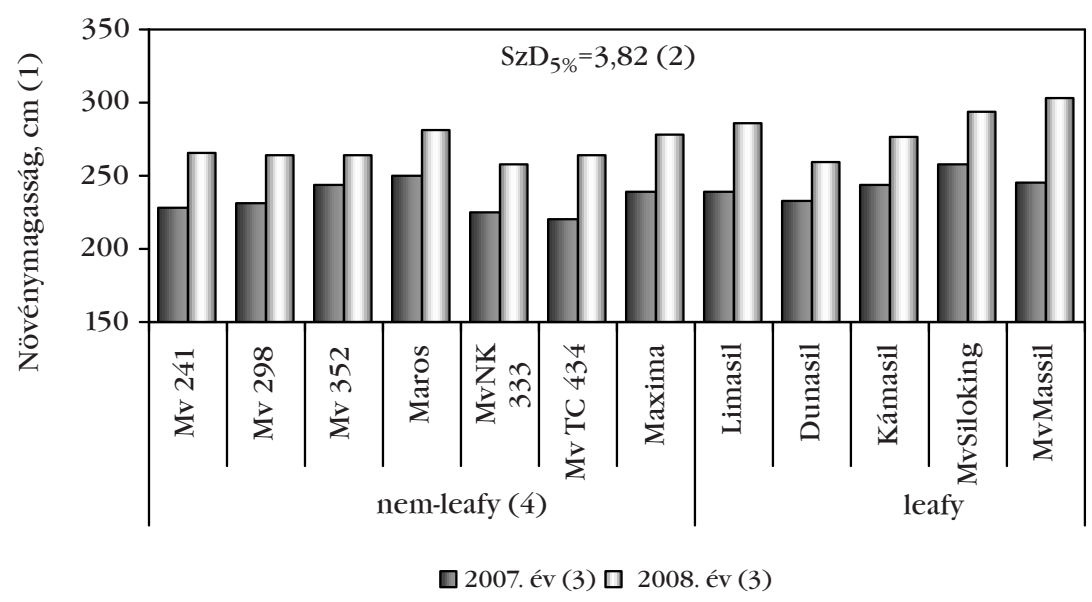

Figure 2. Plant height $(\mathrm{cm})$ of leafy and non-leafy silage maize hybrids in the experimental years. (1) Plant height, (2) $\mathrm{LSD}_{5 \%}$, (3) Year, (4) Non-leafy.

\section{Fốcsố feletti levélterület}

Mindkét évben a leafy hibridek fócső feletti levélterülete volt a nagyobb, két év átlagában a konvencionális nemesítésú hibrideké $0,41 \mathrm{~m}^{2}$, a leafy hibrideké $0,71 \mathrm{~m}^{2}$ volt (a különbség szignifikáns volt) (3. ábra). A nagyobb asszimilációs levélterületet a leafy hibrideknél a nagyobb fốcső fölötti levélszám (leafy: 9,9 db, nem-leafy: 6,4 db), valamint a szélesebb leveleik eredményezték (leafy: 10,5 cm; nem-leafy: 9,4). Két év átlagában a nem-leafy hibridek fốcsố fölötti fiatal és aktivan fotoszintetizáló levélterülete $0,35-0,45 \mathrm{~m}^{2}$, a leafy hibrideké $0,53-0,84 \mathrm{~m}^{2}$ közötti intervallumban változott.

\section{Egyedi csôtömeg produkció}

A vizsgált hibridek egyedi csôtömeg produkcióját jelentôsen módosította az évjárat. A legnagyobb egyedi csôtömeg a leafy hibrideket jellemezte mindkét évben (174,6 g/növény; 306,0 g/növény), ennél a teljesítménynél igazolhatóan kisebb volt a nem-leafy hibridek produkciója (162,9 g/növény; 274,0 g/növény) (2. táblázat). Mindkét évben a nagyobb hozamokhoz elsôsorban a nagyobb ezerszemtömeg és a hosszabb csövek járultak hozzá. Két év átlagában a leafy hibridek ezerszemtömege igazolhatóan nagyobb volt (353,9 g), mint a 
nem-leafy hibrideké (338,6 g). Ugyancsak két év átlagában a leafy hibridek fócsövének hossza $19,2 \mathrm{~cm}$, a nem leafy hibrideké $18,7 \mathrm{~cm}$ volt. A növényenkénti csôszámban ugyanakkor nem találtunk igazolható eltérést a kétféle típusú (leafy, nem-leafy) silókukorica között (leafy: 1,9; nem-leafy 1,9 db/növény).

3. ábra. A fö́csố feletti levélterület $\left(\mathrm{m}^{2}\right)$ és levélszám alakulása a leafy és nem-leafy hibrideknél a 2007-2008. évek átlagában

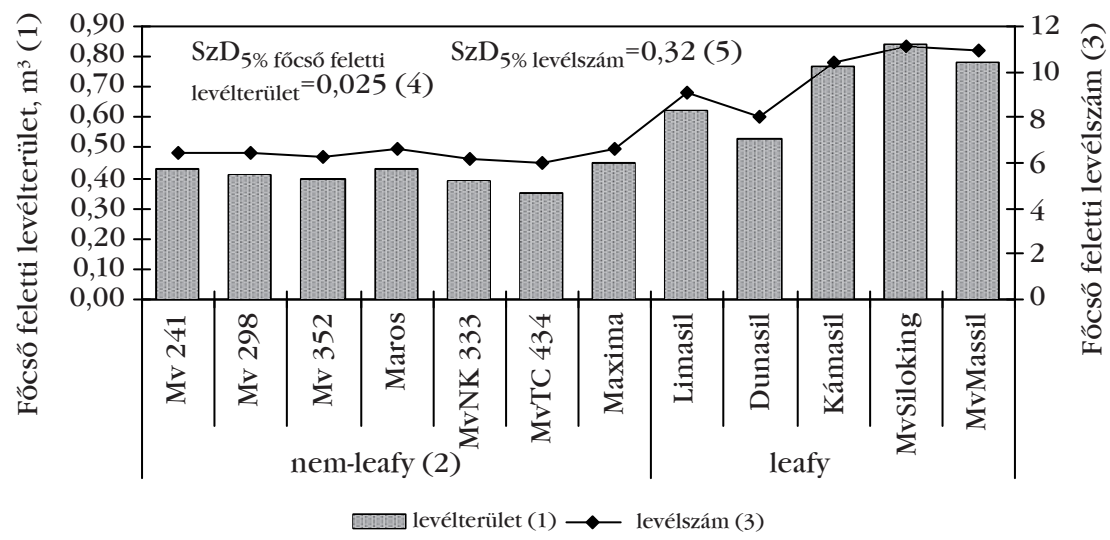

Figure 3. Leaf area ( $\mathrm{m}^{2}$ per plant) and leaf number above the main ear in leafy and non-leafy hybrids, averaged over 2007 and 2008. (1) Leaf area above the main ear, $\mathrm{m}^{2}$, (2) Non-leafy, (3) Leaf number above the main ear, (4) $\mathrm{LSD}_{5 \%}$ leaf area, (5) $\mathrm{LSD}_{5 \%}$ leaf number.

\section{Beltartalmi minöség}

A szemtermés keményítőtartalma szoros korrelációban alakult az egyedi produkcióval. A 2008-ban lehullott több csapadék hatására nagyobb mérvú volt a keményítô beépülése a szemekbe, mint az aszályos 2007-es esztendőben (4. $a ́ b r a)$. Mindkét évben a leafy hibridek keményítőtartalma nagyobb volt $(70,4$; $72,4 \%)$, mint a nem-leafy hibrideké (69,3; 71,7\%). Két év átlagában a nem-leafy hibridek közül a legnagyobb keményítôtartalma a Maros hibridnek (71,8\%), a leafy hibridek közül a Limasil hibridnek $(72,2 \%)$ volt. A szemtermés fehérjetartalma - a keményítótartalommal ellentétben - az aszályos 2007-es évben nagyobb (9,9\%), csapadékosabb évjáratban (2008) igazolhatóan kisebb (8,7\%) volt. Mindkét évben a nem-leafy hibridek mintáiban nagyobb fehérjetartalmakat mértünk (10,0;8,9\%), mint a leafy hibridekében (9,6; 8,3\%). A 2007 es száraz évjáratban nagyobb volt a szemek olajtartalma, mint csapadékos 2008-as évben. A nem-leafy hibridek olajtartalma 2007-ben igazolhatóan na- 
gyobb volt (3,3\%), mint a leafy hibrideké (2,9\%), 2008-ban e paraméter tekintetében a kétféle típusú silókukorica között nem volt megbízható eltérés (4,1; $4,1 \%)$.

2. táblázat. A leafy és nem-leafy silókukorica hibridek egyedi produkciója és néhány terméseleme, 2007-2008.

\begin{tabular}{|c|c|c|c|c|c|c|}
\hline \multirow{2}{*}{$\begin{array}{c}\text { Tulajdonságok } \\
\text { (1) }\end{array}$} & \multicolumn{2}{|c|}{2007} & \multicolumn{2}{|c|}{2008} & \multicolumn{2}{|c|}{ átlag (3) } \\
\hline & leafy & $\begin{array}{c}\text { nem- } \\
\text { leafy (2) }\end{array}$ & leafy & $\begin{array}{c}\text { nem- } \\
\text { leafy (2) }\end{array}$ & leafy & $\begin{array}{c}\text { nem- } \\
\text { leafy (2) }\end{array}$ \\
\hline \multirow{2}{*}{ Egyedi csőtömeg, g (4) } & 174,6 & 162,9 & 306,0 & 274,0 & 240,3 & 218,5 \\
\hline & \multicolumn{2}{|c|}{$\mathrm{SzD}_{5 \%}(8)=5,64$} & \multicolumn{2}{|c|}{$\mathrm{SzD}_{5 \%}(8)=6,89$} & \multicolumn{2}{|c|}{$\mathrm{SzD}_{5 \%}(8)=6,26$} \\
\hline \multirow{2}{*}{ Csőhossz, cm (5) } & 16,7 & 17,3 & 21,6 & 20,0 & 19,2 & 18,7 \\
\hline & \multicolumn{2}{|c|}{$\operatorname{SzD}_{5 \%}(8)=0,24$} & \multicolumn{2}{|c|}{$\mathrm{SzD}_{5 \%}(8)=0,58$} & \multicolumn{2}{|c|}{$\mathrm{SzD}_{5 \%}(8)=0,30$} \\
\hline \multirow{2}{*}{$\begin{array}{l}\text { 1000-szemtömeg, g } \\
(6)\end{array}$} & 347,1 & 328,3 & 360,6 & 348,9 & 353,8 & 338,6 \\
\hline & \multicolumn{2}{|c|}{$\operatorname{SzD}_{5 \%}(8)=11,23$} & \multicolumn{2}{|c|}{$\mathrm{SzD}_{5 \%}(8)=9,85$} & \multicolumn{2}{|c|}{$\mathrm{SzD}_{5 \%}(8)=5,64$} \\
\hline \multirow{2}{*}{$\begin{array}{l}\text { Cső/növény, db } \\
\text { (7) }\end{array}$} & 1,8 & 1,8 & 1,9 & 1,9 & 1,9 & 1,9 \\
\hline & \multicolumn{2}{|c|}{$\mathrm{SzD}_{5 \%}(8)=0,07$} & \multicolumn{2}{|c|}{$\mathrm{SzD}_{5 \%}(8)=0,08$} & \multicolumn{2}{|c|}{$\operatorname{SzD}_{5 \%}(8)=0,08$} \\
\hline
\end{tabular}

Table 2. Yield per plant and yield components of leafy and non-leafy silage maize hybrids, 20072008. (1) Traits, (2) Non-leafy, (3) Average, (4) Ear mass per plant, (5) Ear length, (6) 1000-kernel mass, (7) Ear per plant, (8) $\mathrm{LSD}_{5 \%}$.

\section{Biogáz kihozatal}

A silókukorica fajták anaerob fermentációja során a Limasil, a Dunasil és a Maros fajtákból termelődött a legtöbb biogáz (495, 490, 481 l/kg) $1 \mathrm{~kg}$ szárazanyagra vonatkoztatva (5. ábra). Mind a két leafy hibrid (Limasil, Dunasil), mind a hagyományos nemesítésú silókukorica hibrid (Maros) a korai éréscsoportba tartoznak. A termelt gáz mennyisége és a FAO szám közötti korreláció értéke -0,64, ami közepes erôsségú, negatív elôjelú, szignifikáns összefüggést mutatott. A vizsgált hibridek átlagában a kigázosodás átlagos mértéke $87,37 \%$ volt. A legnagyobb értékeket az Mv Limasil (89,5\%), illetve a Maros (88,63\%) fajtáknál mérték. 
4. ábra. A leafy és nem-leafy silókukorica hibridek keményitố- és fehérjetartalma (2008)

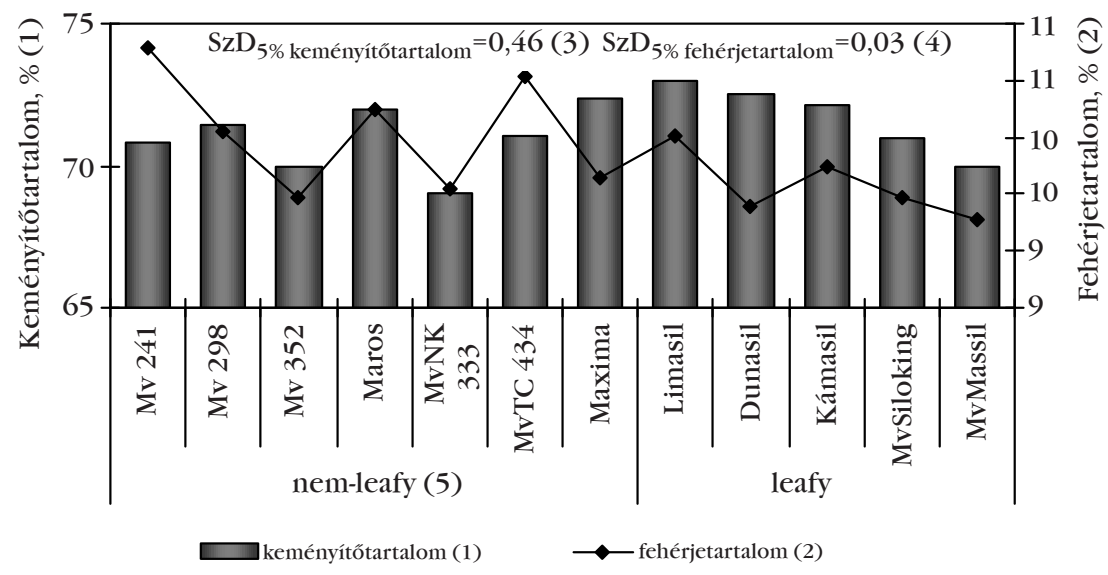

Figure 4. Starch and protein contents of leafy and non-leafy hybrids, in 2008. (1) Starch content, (2) Protein content, (3) $\mathrm{LSD}_{5 \%}$ starch content, (4) $\mathrm{LSD}_{5 \%}$ protein content, (5) Non-leafy.

\section{5. ábra. A fajlagos biogáz kihozatal leafy és nem-leafy hibrideknél (2008)}

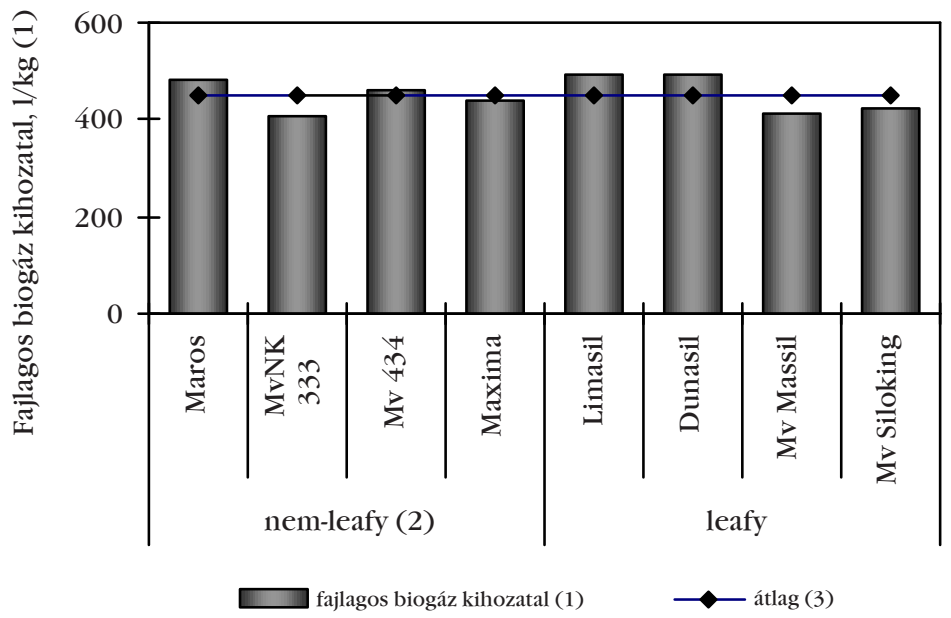

Figure 5. Specific biogas yield by leafy and non-leafy hybrids, 2008. (1) Specific biogas yield, (2) Non-leafy, (3) Average. 


\section{Következtetések}

Kísérletünkben nem-leafy (hagyományos nemesítésú) és leafy silókukorica hibrideket hasonlítottunk össze agronómiai, beltartalmi tulajdonságok, valamint biogáz kihozatal alapján. Más szerzőkhöz hasonlóan megállapítottuk (Shaver 1983), hogy a leafy hibridek magasabbra nôttek, nagyobb volt a fócsó fölötti levélterületük, mint a nem-leafy hibrideknek. Kísérletünkben - az irodalmi adatokkal megegyezóen - a leafy hibridek fő́csövei alacsonyabban helyezkedtek el, mint a nem-leafy hibrideké. A nagyobb, fốcsô fölötti asszimilációs levélterületnek köszönhetôen a leafy hibridek egyedi produkciója volt a legnagyobb, ehhez elsôsorban a hosszabb csövek és a nagyobb ezerszemtömeg járult hozzá (Stewart és Dwyer 1993, Begna et al. 2001). A leafy hibridek szemtermésében nagyobb keményítőtartalmakat mértünk, mint a hagyományos nemesítésú hibridekében. A leafy hibrideknél tapasztalt nagyobb biogáz kihozatal valószínú ennek is köszönhetô. Korábbi megállapításainkkal összhangban a 2007-es aszályos évben nốtt a kísérletben szereplő hibridek (leafy, nem-leafy) szemtermésének fehérje- és olajtartalma, a csapadékos 2008-as évben pedig a nagyobb keményítôbeépülés volt megfigyelhetô (Hegyi et al. 2001).

\section{Köszönetnyilvánítás}

A projekt az Európai Unió támogatásával, az Európai Regionális Fejlesztési Alap társfinanszírozásával valósult meg. Pályázat azonosítója: GOP-1.1.107/1-2008-0080.

\section{IRODALOM}

Andrews, C. J.-Dwyer, L. M.-Stewart, D. W.-Dugas, J. A.-Bonn, P.: 2000. Distribution of carbohydrate during grainfill in Leafy and normal maize hybrids. Can. J. Plant Sci. 80. 1: 87-95.

Begna, S. H.-Hamilton, R. I.-Dwyer, L. M.-Stewart, D. W.-Cloutier, D.-Assemat, L.Foroutan-pour, K.-Smith, D. L.: 2001. Morphology and yield response to weed pressure by corn hybrids differing in canopy architecture. Eur. J. Agron. 14: 293302. 
Dijak, M. A.-Modarres, M.-Hamilton, R. I.-Dwyer, L. M.-Stewart, D. W.-Mather, D. E.Smith, D. L.: 1999. Leafy reduced-stature maize hybrids to short-season environments. Crop Sci. 39: 1100-1110.

Dwyer, L. M.-Andrews, C.J.-Stewart, D. W.-Ma, B. L.-Dugas, J. A.: 1995. Carbohydrate levels in field-grown leafy and normal maize genotypes. Crop Sci. 35: 1020-1027.

Gömann, H.-Kreins, P.-Osterburg, B.-Breuer, T.: 2007. Nutzungskonkurrenzen durch die Förderung von Biogas und anderen Energieträgern. Agrarspectrum. 40: 135-150.

Gyenes-Hegyi, Zs.-Kizmus, L.-Záborszky, S.-Marton, L. Cs.: 2001. Trend sin the protein and oil contents and thousand kernel mass of maize under various ecological conditions. Növénytermelés. 50. 4: 385-435.

Modarres, A. M.-Hamilton, R. I.-Dwyer, L. M.-Stewart, D. W. -Dijak, M. -Smith, D. L.: 1997. Leafy reduced-stature maize for short-season environments: Yield and yield components of inbred lines. Euphytica 97: 129-138.

Montgomery, E. G.: 1906. What is an ear of corn? Popular Sci. Mon. 68: 55-62.

Perry, T. W.-Caldwell, D. M.: 1969. Comparative nutritive value of silages made from high sugar male sterile hybrid corn and regular sterile hybrid corn and regular starch corn. J. Dairy Sci. 52: 1113-1117.

Schittenhelm, S.: 2008. Chemical composition and methane yield of maize hybrids with contrasting maturity. Eur. J. Agron. 29: 72-79.

Shaver, D. L.: 1983. Genetics and breeding of maize with extra leaves above the ear. Proceedings of the Annual Corn and Sorghum Industries Research Conference. 38: 161-180.

Stewart, D. W.-Dwyer, L. M.: 1993. Mathematical characterisation of leaf shape and area of maize hybrids. Crop Sci. 39: 422-427.

Subedi, K. D.-Ma, B. L.: 2005. Ear position, leaf area, and contribution of individual leaves to grain yield in conventional and leafy maize hybrids. Crop Sci. 45: 2246-2257.

Weiland, P.: 2006. Biomass digestion in agriculture: a successful pathway for the energy production and waste treatment in Germany. Eng. Life Sci. 6: 302-309.

Weiland, P.: 2007. Biogas. Stand und Perspektiven der Erzeugung und Nutzung in Deutschland. Agrarspectrum. 40: 111-122.

A szerzôk levelezési címe - Address of the autors:

Dr. Hegyi Zsuzsanna-Tóthné Zsubori Zsuzsanna-Rácz Ferenc

MTA Mezőgazdasági Kutatóintézet

Martonvásár

Brunszvik út 2.

H-2462 